\title{
Freedom of ReLigion in the Brazilian Supreme Court in a Period of Three Decades
}

\author{
Fernanda Duarte* \\ Rafael Mario Iorio Filho**
}

\begin{abstract}
Judicial institutions which provide legal mechanisms for conflict resolution play an important role in maintaining the social order of complex societies. Weaknesses in the performance of their duties can contribute to social conflict developing into outright violence that will be beyond the management of law and the courts. In this sense it is strategic to study the judicial system and the decision-making processes of its judges if one wants to understand the ways conflicts are dealt in a certain place and time. In this article we focus our attention on the role of the Brazilian Federal Supreme Court as custodian of the Constitution and the discourses that its decision-making construct when dealing with human rights issues. Specifically we set out to understand how the opinions of Brazilian Supreme Court Justices are constructed when deciding cases concerning freedom of religion. The timeline considered covers 31 years, from 1988 to 2019, a period that begins with the promulgation of the new constitution in 1988 (which symbolically reinstated democracy in the country after the end of the period of military rule that began in 1964) up to the present day. We begin by presenting the legal definition of freedom of religion in Brazil which constitutes the normative background of the discussion. We then discuss our project, stressing the methodological approach we have adopted and finally we present our data findings. We identified 39 cases in total of which 11 were selected and analyzed using the methodology of Semiolinguistic Discourse Analysis in order to define the semantic field related to freedom of religion in Brazil. Even though the number of cases is not large it is possible to identify some features of Brazilian legal culture which are also recurrent when dealing with religious freedom. One of these features is the absence of consensus-building logic in the Justices'opinions-we attribute this to what we term the disputatio mindset - which contributes to continuing institutional instability and legal insecurity. Our findings suggest that these Supreme Court decisions frequently lack the strong level of rational consistency that lower courts require if they are to identify clear guiding principles that can control the outcomes of new cases
\end{abstract}

\section{KEYWORDS}

Brazilian Legal Studies, Brazilian Legal Culture, Freedom of Religion, Brazilian Supreme Court (STF)

\footnotetext{
* Professor of Law, Federal Judge, Ph.D. - PPGD/UNESA, PPGJA e INCT-InEAC/UFF. Email: fduarte1969@yahoo.com.br.

** Professor of Law, Ph.D. - PPGD/UNESA, PPGJA e INCT-InEAC/UFF. Email: rafa. ioriofilho@gmail.com.
} 


\section{CONTENTS}

I. Some Features of Religious Practice in BraziL 443

II. The Research Project: Freedom of Religion in the Brazilian Supreme Court in Three DeCades (1988-2019) 450

A. The Legal Definition of Freedom of Religion in BrazilThe Normative Perspective of the 1988 Brazilian Constitution, Article 5, VI 450

B. The Brazilian Supreme Court (Supremo Tribunal Federal-STF) 453

C. The Project. 454

III. DATA FINDINGS 456

A. Building up the Corpus: Defining the Sources for Consultation \& Selecting the Decisions. 457

B. The Semantic Field. 458

C. Preliminary Results. 459 


\section{Some Features of Religious Practice in BraziL}

Religion in Brazil has played a prominent role in people's lives and society's design and one might say even a strategic one since the beginnings of the European occupation of the land by the Portuguese. ${ }^{1}$ The culture of Brazilian people is intertwined with religion or faith in some way and the entire country has been remarkably shaped by religious practices. ${ }^{2}$ On the one hand, it is easy to identify this influence in the celebrations, festivals, traditions, customs and other cultural activities which are all related at some level to religious motives and beliefs. For example, many of the annual Brazilian festivals and events are based upon the traditions of the Roman Catholic church, notably the famous Carnival which is held 40 days before Easter and is the last festive celebration before liturgical Lent. On the other hand, religious influence runs deep within the Brazilian ethos, adding an extra flavor to Brazilian identity (Brasilidade) and shaping the social, cultural and political fabric of the country.

The two institutions naturally suited for organizing the colonization of Brazil were the State and the Catholic church. [...] In principle, there was a division of labor between these two institutions. The state had the fundamental role of guaranteeing Portuguese sovereignty over the colony [...] This task presupposed that settlers in Brazil recognized the authority of the state - because they were forced to, because they agreed to, or for both reasons.

This is where the church came in. Since it was in charge of people's behavior and "in control of their souls" in daily life, it was a very efficient means for conveying the idea of obedience and, strictly speaking, obedience to the power of the state. But that was not all the church would do. It was present throughout people's lives - in the decisive episodes of their birth, marriage, and death. ${ }^{3}$

1 See Boris Fausto \& Sergio Fausto, A Concise History of Brazil (2014). The authors observe: "The Portuguese reached the coast of what today is Brazil in April 1500. This occurrence was but one of the many episodes of Portuguese overseas expansion, which began early in the $15^{\text {th }}$ century", $i d$. at 1 , and "[...] one should not forget that at the beginning of the $15^{\text {th }}$ century, overseas expansion served the varied interests of the diverse classes, social groups, and institutions that constituted Portuguese society. [...] For the nobles and for the Church, to serve the king or to serve God by bringing Christianity to the heathen entailed rewards [..]". Id. at 2-3.

2 As Darcy Ribeiro - one of Brazil's leading twentieth-century intellectuals - explains "Brazilian society and culture have been shaped as variants of the Portuguese version of traditional western European civilization, differentiated by tones inherited from American Indians and African blacks. Brazil thus emerges as a renewed mutant, expressing its own characteristics but generically tied to its Portuguese origins, which involved unsuspected potential for existence and growth that would only be fully realized here". DARCY Ribeiro, The Brazilian People: The Formation and Meaning of Brazil 1 (Gregory Rabassa trans., 2000).

3 FAUSTO \& FAUSTO, supra note 1, at 23. Note also: "Membership in a particular community, being able to live a decent life, and having a sinless departure from this 'vale of tears' depended on ceremonies monopolized by the church: baptism, confirmation, matrimony, 
According to journalist Sarah Brown, "Brazil is the most religious country in Latin America, with approximately 90 percent of all Brazilians associating themselves with some religion." "The latest official report produced by the Brazilian Institute of Statistics (IBGE) - Census 2010 - shows that only 15 million people in total identify themselves as "irreligious" (which would include not only people with no affiliation but atheists as well). ${ }^{5}$

Moreover, "it is also the most religiously diverse nation on the continent, thanks to African influences from slavery 500 years ago, and more recent migration from Asia, Europe and the Middle East." ${ }^{.6}$

Due to its Portuguese heritage, it is the case that most Brazilian people are linked to the Roman Catholic Church and there are more Roman Catholics in Brazil than in any other country in the world. ${ }^{7}$ The Catholic Church itself has played a distinguished role in the Brazilian history of human rights. For instance, as noted by the Religious Literacy Project, hosted by Harvard Divinity School, even though the Church supported Vargas`s dictatorship during the thirties, it has been a champion for redemocratization and the defense of human rights against the military regime which lasted from mid-sixties to mid-eighties of the last century.

The endorsement of human rights, democracy, and religious freedom by the Second Vatican Council provided an official theological language within which to frame such concerns. The catalyzing event for the Church was the rise of military dictatorships between 1964 and 1980, which deepened Brazil's economic woes and ushered in a dark era of suppression, censure, torture, and killings, including those of Catholic priests, nuns and bishops.

In response, the Catholic Church in Brazil underwent a transformation from conservative buttress to the state in the 1930 s to a prominent critical voice against capitalism and political policy, becoming the most radically progressive of the Latin American Catholic Churches. Priests

confession, extreme unction in the hour of one's death, and burial in a cemetery known by the weighty term campo santo or holy field". Id.

4 Sarah Brown, Everything You Need to Know About Brazil's Diverse Religious Beliefs, CUlTURE TRIP (April 8, 2017), https://theculturetrip.com/south-america/brazil/articles/ everything-you-need-to-know-about-brazils-diverse-religious-beliefs/ (last visited Mar. 14, 2020).

5 IBGE, Censo 2010: número de católicos cai e aumenta o de evangélicos, espíritas e sem religião (in Portuguese). http://www.ibge.gov.br/home/presidencia/noticias/noticia visualiza.php?id_noticia=2170\&id_pagina=1 (last visited Mar. 14, 2020).

6 Brown, supra note 4.

7 "The Catholic Church is deeply enmeshed in Brazil's culture, beliefs, and institutions. The Church arrived with the Portuguese conquest in the sixteenth century and has since been the dominant religion. From 1500 to 1889, Catholicism was the official state religion. Even after disestablishment and the efforts at secularization that began under the First Republic (1889-1930), the Catholic Church retained its property holdings and continued to play a significant role in public ritual and private social life."(https://rlp.hds. harvard.edu/faq/catholic-church-brazil. Last visited 15 Jan., 2020). A detailed account about the Catholic Church in Brazil up to the seventies is provided by Philip Raine, The Catholic Church in Brazil, 13 J. Interamer. Stud. \& World AfFairs 279 (1971). 
and bishops joined the struggle for labor and land rights and in coming decades worked to expose abuses committed by the military junta. The Church organized community groups meant to address basic concerns among the poor, but which later became politicized under the military dictatorship. Underpinning these changes was the development of Latin American liberation theology, a set of ideas which emphasize the role and rights of the poor and marginalized, and social justice as salvation. Ultimately, the Church emerged as the primary oppositional voice against the military and facilitated the transition to democracy in the 1980s by allying itself with grassroots movements, trade unions, and opposition political parties. ${ }^{8}$

Protestantism is the largest minority religion in Brazil, with approximately 22 percent of the population practicing one of the Protestant doctrines. But numbers have grown in recent years, with some predictions that in the near future it will be the predominant religion in the country. ${ }^{9}$ Within Protestantism, it seems that Pentecostals (or Neo Pentecostals) make up the largest group:

Pentecostalism is the fastest growing sector of Brazilian Protestantism. It is made up of Classic Pentecostalism, founded by European and American missionaries during the first half of the twentieth century, and NeoPentecostalism, a later generation of indigenous churches that emerged after 1970. The first group includes such significant denominations as the Christian Congregation, the Assembly of God, Church of the Foursquare Gospel, Brazil for Christ, and God is Love. Major Neo-Pentecostal churches include Sara Our Land Evangelical Community, Universal Church of the Kingdom of God, the International Church of the Grace of God, and Reborn in Christ. ${ }^{10}$

8 Harv. Div. Sch., Religious Literacy Project, https://rlp.hds.harvard.edu/faq/catholicchurch-brazil (last visited Mar. 14, 2020).

9 Reinaldo Azevedo, Blog do jornalista Reinaldo Azevedo: política, governo, PT, imprensa e cultura. O IBGE e a religião - Cristãos são 86,8\% do Brasil; católicos caem para 64,6\%; evangélicos já são 22,2\% (18 Feb. 2017, 14h58), https://veja.abril. com.br/blog/reinaldo/o-ibge-e-a-religiao-cristaos-sao-86-8-do-brasil-catolicos-caempara-64-6-evangelicos-ja-sao-22-2/ (last visited Mar. 14, 2020).

10 Harv. Div. SCH., Religious Literacy Project, https://rlp.hds.harvard.edu/faq/ pentecostalism-brazil (last visited 14 Mar., 2020). "Most members are poor, black and female with limited education. This reflects the history of Pentecostalism, which sought out impoverished Brazilians as rural networks began disintegrating, urbanization increased, and economic modernization heightened the marginalization of many, particularly Afro-Brazilians. Prior to the emergence of Liberation Theology, the Catholic Church failed to institutionally address the needs and interests of the growing poor and Pentecostal churches proliferated among these populations. Pentecostal congregations offered a replacement community with strong prohibitions against the temptations of urban life (drink, drugs, sex, gangs, in some cases, television). The emphasis on adherence to doctrine and devotion to prayer rather than Biblical knowledge and learning offered a comfortable space and opportunities for church leadership to the often illiterate laborers. Finally, with their theological emphasis on individual salvation and an unmediated relationship with Jesus, these churches stressed an ethos of individuality that resonated with those outside the existing client-patron structure. More recently, Neo- 


\section{As Professor Neil Turner describes,}

Typically, evangelical Protestant Christianity in Brazil is characterized by a strong opposition to Catholicism in terms of socio and political economics. Over the past two decades, it has successfully played an important role in modifying the lives of the educationally and economically disadvantaged. In fact, evangelical Christianity and Pentecostalism in particular have provided significant stability in the lives of many of its followers in terms of social and economic progress by penetrating lives at the cultural level. ${ }^{11}$

Pentecostals are now being portrayed as a political force to be reckoned with, although political analysis of their action may vary as appears below: ${ }^{12}$

The Pentecostals are increasing political participation, but they are doing so in a conservative way. Their leaders have sought not to alter but simply to adapt to Brazil's socioeconomic structure and political system. Pentecostal politicians are especially known for seeking patronage and privileges. In Brazil the poor do not want to revolt but to ascend the social ladder. The Pentecostal churches reflect this hope. Especially among the newer churches the primary concern of the leaders is power, and often their theologies are attuned to economic interests. The new churches have little notion of social justice on a national scale. ${ }^{13}$

Significant changes at the social level have necessitated the development of political interests and incorporated followers into the democratic political process. As a result, evangelical Protestants have become an increasingly powerful segment of the voting bloc in which presidential, congressional and senatorial candidates are courting them for support. As more evangelical candidates are elected to office in the house and senate, many vow to oppose attempts to legalize issues such as abortion, the death penalty, or homo sexual unions which they consider a breach

Pentecostalism's embrace of the Prosperity Gospel, associating upward social mobility with devotion, also contributed to its widespread appeal among the urban poor and middle class". Id.

11 Neil Turner, Religious Syncretism in Brazil: Catholicism, Evangelicalism and Candomblé (2011), https://www.grin.com/document/165645 (last visited Mar. 14, 2020).

12 "Pentecostalism entered politics in the 1990s, with large voting blocs throwing their substantial weight behind Pentecostal and church-endorsed candidates, oftentimes church pastors and bishops running for office. Though Pentecostal churches initially lacked the organized political networks that the Catholic Church cultivated during the military dictatorship, they successfully leveraged their evangelical structure, processes, and culture. Many Pentecostals perceive political participation as a religious duty, another battleground in the ongoing spiritual war against demonic influences, with individual and communal health, wealth, and salvation at stake. This belief forges a fervent commitment to candidates and cause." HaRv. Div. SCH., supra note 10.

13 Kenneth P. Serbin, The Catholic Church, Religious Pluralism and Democracy in Brazil 5 (1999), https://kellogg.nd.edu/sites/default/files/old_files/documents/263.pdf (last visited Mar. 14, 2020). 
of their faith. While these issues are important, many evangelical voters are more concerned with social issues such as reducing poverty, crime and unemployment. ${ }^{14}$

As the Religious Literacy Project notes there is a strong African influence within the sector:

African-derived religions in Brazil ${ }^{15}$ include, most prominently, Candomblé and Umbanda, as well as Xango, Batuque, Cantimbo, and Macumba, which are regionally associated traditions. African-derived religions have played an important role in the formation of AfroBrazilian ethnic identities, both historically and today. Such traditions have been both celebrated and denigrated at different times and by different actors, from the Catholic Church in the post-independence era-which characterized them as evidence of "backwards" African culture and Afro-Brazilians as failing to become "true Catholics"- to today's Pentecostals, who condemn Candomblé and Umbanda as "devil worship." 16

As for their practices, the supernatural realm is a characteristic of their beliefs and rituals:

As suggested by the common Brazilian saying, "if one does not come due to love, one comes due to pain," solving the problems of life, particularly physical healing, is central to both Candomblé and Umbanda. Illness, diagnosis, and cure all have a supernatural aspect and many of the religious rituals are strategies for maintaining or restoring physical, mental, or social well-being. Possession is another characteristic of African-derived religion, locating liminality within the physical being. ${ }^{17}$

14 Turner, supra note 11, at 5 (footnote omitted).

15 “[...] today's practices represent an amalgam of various traditions, which continue to evolve in conversation with practitioners in Nigeria and elsewhere in West Africa. Though statistics report that Candomblé and other African-derived religious participants are few in number - under $5 \%$ of the population - this fails to reflect the many Brazilians who are not initiates but who nonetheless may visit a practitioners [ $\mathrm{sic}]$ (such as a healer), perhaps to address a challenge around health, money, or love. In fact, the 2010 census found that $13 \%$ of the Brazilian population claim to have more than one religion, usually Catholic and Umbanda or Catholic and Spiritist". Harv. Div. SCH., Religious Literacy Project, https://rlp.hds.harvard.edu/faq/african-derived-religions-brazil (last visited Mar 14. 2020).

16 Id. "Though statistics report that Candomblé and other African-derived religious participants are few in number - under $5 \%$ of the population - this fails to reflect the many Brazilians who are not initiates but who nonetheless may visit a practitioners (such as a healer), perhaps to address a challenge around health, money, or love. In fact, the 2010 census found that $13 \%$ of the Brazilian population claim to have more than one religion, usually Catholic and Umbanda or Catholic and Spiritist". Id.

$17 \quad$ Id. 
A very important distinguishing feature of African-Brazilian religions is what has been described as syncretism, ${ }^{18}$ which derives from a blending of different religions giving birth to a new one.

According to Wagner Kuhn,

The African people who were sold to colonial Brazil brought with them their religious beliefs and traditions. In order to survive the inquisitorial atmosphere of the Portuguese colonizers, many of the African slaves needed to mask their deities and saints or ancestors with Roman Catholic names. This process gave birth to the Afro-Brazilian religions - $\mathrm{a}$ form of dual allegiance that blends together various elements of Roman Catholicism, African Religions, and Kardecist spiritualism. ${ }^{19}$

In this sense, slavery with its power tensions ${ }^{20}$ has played a fundamental role in determining this blending of beliefs and the survival of African religious heritage. Kuhn goes on to observe:

From different communities and religious backgrounds, the slaves were mixed aboard the ships and then, at the final trade centers they were bought and also sent to different places of Brazil. This created a big impact upon the new environment in which they were placed. It transformed their reality. For they were lost, they were weak, and they wanted to survive, so they found a way to maintain their religious tradition: they masked their deities with Christian names-Roman Catholic ones.

$[\ldots]$

18 For more about syncretism in religions, especially regarding the theoretical debate around the category, see Syncretism in Religion: A Reader 2-28 (Anita Maria Leopold \& Jeppe Sinding Jensen eds., 2014). Syncretism relating to African-Brazilian religions is also subject to many criticisms, such as may be found in Stefania Capone, Re-Africanisation in Afro-Brazilian Religions: Rethinking Religious Syncretism, in Handbook of Contemporary Religions in Brazil 473 (Bettina Schmidt \& Steven Engler eds., 2016). There is a very interesting piece by Ilé Axé Opô Afonjá which denies that syncretism constitutes Candomblé and states that Candomblé is not a sect, but a religion independent from Catholicism. See Ilé Axé Opô Afonjá, Iansã is not Saint Barbara, in The Brazil Reader: History, Culture, Politics 408-10 (Robert M. Levine \& John J. Crocitti eds., 1999).

19 Wagner Kuhn, Understanding Religious Syncretism in Brazil: Cases in Dual Allegiance with Implications for Adventist Mission, 7 Hermenêutica 19 (2007) (citation omitted) (copy available at http://www.seer-adventista.com.br/ojs/index.php/hermeneutica/ article/view/205 (last visited Mar. 14, 2020)).

20 This tension is described by Leopold and Jensen: "Other syncretistic formations have emerged as the consequence of a dominant culture forcing on or "interpenetrating [...] a culture of minority its own religion such as to make it the official religion. In those cases, syncretism may be seen as a result of a resistance to power and a means to preserve indigenous gods in the clothing of the gods of the dominant culture. In certain cases, this form has been called "creolization" with reference to the dominance of the Christian culture upon Afro Caribbean or Afro-American cultures." Leopold \& Jensen, supra note 18 , at 4 . 
Religious life in the slave communities was very difficult. The African slaves could not have their own religious services in a normal way. They were baptized into the Catholic faith without any regard of their will. There "they were obliged to camouflage their cults and saints with Christian names" and so they gradually learned to adapt themselves to the new system. Van Rheenen commented that "although the slaves were forced to outwardly embrace Catholicism, the gods that they brought from Africa were intertwined with this new religion." ${ }^{21}$

Nonetheless there were changes as years passed by and this syncretic aspect of Brazilian religiosity has produced a form of religious pluralism which affords the possibility of subscribing to one set of beliefs, with resort to another in time of need. As Kuhn points out,

This scenario described changed drastically during the twentieth century in Brazil, with the emergence of many more forms of spirituality and religious life. In practical terms, religion has been more effective in the transformation of the Brazilian society than science. Moreover, many elements of Roman Catholicism, Evangelical and charismatic Pentecostalism, spiritualism, and African religions have blended together; and science, mysticism, parapsychology, and new age occultism have been added to these syncretistic neo-religions in an unprecedented way. The result is a dual allegiance within the context of a religious pluralism where the believer can seek for both God and the world of spirits at the same time. ${ }^{22}$

Other religions, such as Judaism, Buddhism or Islam, are also professed by some Brazilians, but compared with Christianity their numbers are not significant. As the Brazilian Institute of Statistics (IBGE) 2010 Census shows, altogether they add up to less than 1.04 percent of the Brazilian population. ${ }^{23}$

This religious landscape is also showcased in popular language in many different situations. There is also a national joke to the effect that "God is Brazilian" which reveals, amongst other possible interpretations of the humorous statement, the level of divine worship and confidence in the supernatural of the society in general.

"No matter what ... by the end of the day things will get right ... because "God is Brazilian"!

$21 \quad$ Wagner Kuhn, supra note 19, at 22-3 (citations omitted). Kuhn further observes: "The slaves were used to a life of secrecy. In many places the slaveholders would not allow them to participate in religious activities. In some communities they were granted permission to attend church, but it was a church especially designed for them. In a very precise way Bastide stated that "by permitting the blacks to unite in brotherhoods, the church promoted the syncretism of Catholicism with African religion rather than Catholicization of the blacks." Id. at 23 (citations omitted).

$22 \quad I d$. at 23.

23 See IBGE, Censo Demográfico 2010, https://ww2.ibge.gov.br/home/estatistica/ populacao/censo2010/caracteristicas_religiao_deficiencia/default_caracteristicas_ religiao_deficiencia.shtm (last visited Mar. 14, 2020). 
In recent years, Brazil has also become a strong exponent for "exporting" religious beliefs. ${ }^{24}$ Charismatic Catholic and Pentecostal churches have established powerful transnational networks with a strong missionary focus. Thus in contrast with the "seemingly irredeemable" secularity of Europe, Latin America and Africa have seen an "explosive growth" in the number of their adherents, with Europe and even the United States now moving into the focus of these churches' evangelizing zeal. ${ }^{25}$ The effect may be termed a process of 'reverse missionizing', with the result, suggest Cristina Rocha and Manuel Vásquez, that what is emerging is a "new religious cartography" with the Global South in the protagonist role. ${ }^{26}$

\section{The Research Project: Freedom of Religion in the Brazilian Supreme Court IN Three DeCades (1988-2019)}

This paper is part of a broader body of research in which we are seeking various interpretations of human rights in Brazil and trying to establish their discursive significance and social representation through the use of legal lenses, especially those crafted by the courts. Here we aim to understand how the opinions of the Supreme Court Justices are constructed when deciding cases concerning freedom of religion in Brazil, considering the boundaries above stated. The timeline considered covers 31 years, from 1988 to 2019, a period that begins with the promulgation of the new constitution in 1988 (which has symbolically reinstalled democracy in the country after the military rule that took place in Brazil since 1964) up to 2019 with the presentation of the seminar Global Constitutional Dialogue: Judicial Challenges for the 21st Century: The Judiciary and the Administrative State that has inspired this work. ${ }^{27}$

To accomplish this, first we will present briefly the legal definition of freedom of religion in Brazil which constitutes the normative background of the discussion and then we will discuss our project, stressing the methodological approached we have adopted and showcasing our data findings.

\section{A. The LEGAL DEFINITION OF FREEDOM OF RELIGION IN BRAZIL - The Normative Perspective of the 1988 Brazilian Constitution, ARTICLE 5, VI.}

As noted by anthropologist Professor Paula Montero, "the principle of religious freedom became naturalized in public discourse as a condition indispensable to peace. Its protection remains at the base of the concepts of emancipation, democracy and prosperity that guide contemporary liberal states". ${ }^{28}$

24 Introduction to The Diaspora of Brazilian Religions 6 (Cristina Rocha \& Manuel A. VÁSQueZ (eds.), 2013) (citation omitted).

25 Id.

$26 \quad I d$.

27 Global Constitutional Dialogue: Judicial Challenges for the 21st Century:The Judiciary and the Administrative State, Birmingham City University (September 2019).

28 Paula Montero, Syncretism and Pluralism in the Configuration of Religious Diversity in Brazil 1 (Mecila Working Paper Series, No. 4, 2018. São Paulo: The Maria Sibylla Merian International Centre for Advanced Studies in the Humanities and Social 
Contemporary Brazil ${ }^{29}$ does not stand outside this modern liberal tradition and freedom of religion is guaranteed by the general constitutional paramount clause of article 5 which is the normative basis of fundamental rights/human rights protection within the Brazilian legal system inaugurated by the 1988 Constitution. ${ }^{30}{ }^{31}$ There is also a specific provision written into the Constitution in article 5, subsection VI. ${ }^{32}$

Article 5: All persons are equal before the law, without any distinction whatsoever, Brazilians and foreigners residing in the country being ensured of inviolability of the right to life, to liberty, to equality, to security and to property, on the following terms $[\ldots]$

VI - freedom of conscience and of belief is inviolable, the free exercise of religious cults being ensured and, under the terms of the law, the protection of places of worship and their rites being guaranteed ${ }^{33}$.

Sciences Conviviality-Inequality in Latin America) https://www.researchgate.net/ publication/326957406_Syncretism_and_Pluralism_in_the_Configuration_of_ Religious_Diversity_in_Brazil (last visited Mar. 16, 2020).

29 But this status of freedom has not always been part of Brazilian history. "The first Brazilian Constitution, dated 1824, enacted after the Brazilian declaration of independence from Portugal, stated in its article 52 that the Roman Catholic Church religion was the religion of the country. Other religions were allowed in private or in temples, yet not in public. At the time, church and state were practically one and the King protected and governed the church in his vast domains, by divine right. On November 15th, 1889, Republic was proclaimed and, as a consequence, a second Brazilian Constitution came to light in1891, recognizing religious freedom in its article 72 , sections $3,5,7,28$ and 29, allowing individuals and religious organizations to publicly worship, and the separation between the State and the Catholic Church was declared." Marcelo Moscogliato, Religious Freedom in Brazil - Some Precedents, 1 Revista Eletrônica do Ministério Público FEDERAL 1, 1-6 (2009). http://www.moscogliato.com.br/portugues/artigos/2009a_Dir Pub_Moscogliato\%2001.pdf (last visited Mar. 16, 2020). Since then, the principles of separation of church and state and freedom of religion have been embraced by the other five subsequent Constitutions, being guaranteed in the 1934, 1937, 1946, 1967/1969 and including the last and current one, dated 1988.

30 An English version of Brazil's Constitution of 1988 (with Amendments through 2014) is offered by Constituteproject.org with content generously provided by Keith S. Rosenn. https://www.constituteproject.org/constitution/Brazil_2014.pdf (last visited Mar. 14, 2020). A more current version is available from Brazil's Supreme Federal Court on http://www.stf.jus.br/repositorio/cms/portalStfInternacional/portalStfSobreCorte_pt_br/ anexo/BrazilFederalConstitution_atualizadaataemenda99de2017Eletrni.._.pdf (last visited Mar. 14, 2020).

31 For the purposes of this Article we will assume that when human rights are included in the internal legal order, they are called fundamental rights. They can be provided for in the Constitution or even in fragmented laws. In Brazil, they are provided for in the text of the 1988 Constitution, especially in article 5 .

32 Regarding the way statutes are cited, the Brazilian 'article' would be equivalent to 'section' in the United States. We have opted to use the Brazilian term 'artigo' simply translated as the English 'article', though without implying an intercultural approach to the meaning of the words in both legal cultures.

33 There are other constitutional provisions that deal with religion too, such as art. 150, III "b" ("Art 150 - Without prejudice to other guarantees assured the taxpayer, the Union, 
The effect is to guarantee a pluralist approach and is understood as a way of recognizing different faiths within Brazilian society, at least in the normative domain.

Within this framework, Brazil has in place specific laws and policies that contribute generally to the free exercise of religion. The criminal code secures protection of religious freedom, as does CAÓ Act (Law 7716/1989, of Jan. 5) which defines the crime of racism as the different and disparaging treatment of a person exclusively because of his "race, colour, ethnicity, religion or national origin", which has the effect of preventing him or her from gaining access to certain goods, services or places because of his or her condition. ${ }^{34}$

This legal design has been considered by some as quite a satisfactory legal framework. ${ }^{35}$ But one can find some traces of religious intolerance that in reality threaten the idea of freedom of religion and jeopardize human rights protection. Even though the number of recorded incidents of aggression is not excessive, the violation itself is always symbolic because from "such practice emerge other issues, such as: the invisibilization of people, disrespect for their culture and also the loss of self-esteem and belonging". ${ }^{36}$

States, Federal District and Counties are prohibited from: [...] VI. levying taxes on: [...] b. temples of any religion") for example. But in this paper we are dealing only with art. 5 , VI which is the principal clause to provide for fundamental rights.

34 The crime of racial injury is provided for in article 140, paragraph 3, of the Brazilian Criminal Code (Law DL 2848/1940, of December 07). It is defined as the offense against the dignity of an individual, using references to elements of "race, colour, ethnicity, religion, origin or the condition of a person being elderly or disabled". Dr. Eric Kramer provides an interesting review of a criminal trial held in São Paulo in 1995 when the State of São Paulo prosecuted an evangelical minister on the grounds of verbally and physically assaulting a plaster statue of Our Lady Aparecida (Nossa Senhora Aparecida) who is the patron saint of the country. The case has raised thought-provoking debates within the legal community as well civil society as a whole regarding issues such as the limits of freedom of speech opposed to freedom of religion, majority and minority rights, how freedom relates to the rights and private lives of citizens. Kramer concludes that "Public iconoclasm has exposed the contradictions between the Brazilian state's explicit support of Our Lady of Aparecida as a public religious symbol and the rhetoric in defense of the constitutional principle of religious freedom." Eric W. Kramer, Law and the Image of a Nation: Religious Conflict and Religious Freedom in a Brazilian Criminal Case, 26 LAW \& Soc. InQuiRY 35, 60 (2001).

35 Due to this pluralist religious alliance, one might think that Brazil would exist as a more tolerant society. In fact, the country has been portrayed by some as a peaceful society regarding religious conflicts. This sugarcoated view can be seen in U.S. official documents, such as the International Religious Freedom Report 2010, published by the Bureau of Democracy, Human Rights, and Labor, U.S. Department of State, November 17, 2010. https://2009-2017.state.gov/j/drl/rls/irf/2010/148738.htm (last visited Mar. 20, 2020). Dr. Brian Grim of the Berkley Center for Religion, Peace, and World Affairs, Georgetown University, has published an essay praising Brazil's religious tolerance. See Brian Grim, Brazil: A Lesson in the Peaceful Navigation of Religious Change (Jun. 1, 2015), https://berkleycenter.georgetown.edu/essays/brazil-a-lesson-in-the-peacefulnavigation-of-religious-change(last visited Mar. 20, 2020).

36 Babalawô Ivanir dos Santos et al., CEAP, Intolerância Religiosa no Brasil ReLATÓRIO E BALANÇO (2016), available at https://www.geledes.org.br/wp-content/ uploads/2018/08/relatorio-final-port-2.pdf. (last visited Mar. 20, 2020). "A report released this Thursday, June 13th [2019], by the Ministry of Women, Family and Human Rights 


\section{B. The Brazilian Supreme Court (Supremo Tribunal Federal-STF)}

The Brazilian Supreme Court (STF) is the highest court in Brazil with national jurisdiction over constitutional matters and its rulings cannot be appealed. The language of the Constitution states that the STF has "primary responsibility for safeguarding the Constitution".

Article 102 of the 1988 Constitution provides for the court's jurisdiction; and regarding matters of constitutionality, the court decides on extraordinary appeal, cases decided in sole ${ }^{37}$ or last instance and the court has the additional power to try and to decide, as matters of original jurisdiction, direct claims of unconstitutionality of federal or state normative acts or make declaratory judgments of the constitutionality of federal laws or normative acts. ${ }^{38}$

Judicial review in Brazil, as Professor Keith Rosenn explains, "combines the decentralized, incidental form of judicial review of a common law country like the United States with the centralized, abstract form of judicial review of civil law countries such as Germany and Italy. Brazil's Constitution provides for both forms of judicial review." ${ }^{39}$ This means that both collateral and direct judicial review is available, ie the constitutionality of federal, state or municipal laws or decrees may be challenged in the course of litigation before any state or federal court or

(MMFDH) points out that Brazil is still displaying signs of religious intolerance in the form of physical assault, cursing, burglaries, desecration of images, homicide attempts, and criminal fires. Leading case cities are Natal with 191 cases, followed by São Paulo with 91, and Rio de Janeiro with 61. Natal has led the ranking since 2015." Richard Mann, Rio Times, June 14, 2019, https://riotimesonline.com/brazil-news/rio-politics/ society/brazil-records-over-500-cases-of-religious-intolerance-in-2018/ (last visited Mar. $20,2020)$. This issue has also been considered in other reports. Here we would mention two that were a result of a collaboration between Brazilian NGOs and universities with governmental research funding: the previously mentioned report by dos Santos et al. and Ana Paula Miranda et al., Relatório Sobre a Comissão de Combate à Intolerância Religiosa: BalanÇo de dois anos De atividade (InEAC-UFF, 2010) https://www. academia.edu/40381618/RELAT\%C3\%93RIO_SOBRE_A_COMISS\%C3\%83O_DE COMBATE_\%C3\%80_INTOLER\%C3\%82NCIA_RELIGIOSA_BALAN $\% \mathrm{C} 3 \% 87 \mathrm{O}_{-}$ DE_DOIS_ANOS_DE_ATIVIDADE (last visited Mar. 20, 2020).

37 According to the way jurisdiction is designed in Brazilian courts, "decided in sole" refers to a decision made by a higher court at first and in respect of which there is no provision for appeal, meaning that the case starts and finishes at the same court.

38 It is important to bear in mind that the court has jurisdiction over other criminal and civil cases too which could be considered as non-core duties compared to its position as the defender of the Constitution. Altogether, article 102 has three subsections with 22 items. For example, in subsection I, "n", the Court has original jurisdiction over cases in which all members of the judiciary have a direct or indirect interest, and those in which more than half the members of the originating tribunal are disqualified or have a direct or indirect interest. In subsection I, "o", the court is the mediator of tribunals, arbitrating conflicts of jurisdiction between Brazilian national Higher Courts, such as the Superior Tribunal of Justice and any other tribunals, between Superior Tribunals, or between the latter and any other tribunal. On the other hand, in subsection I "b", the court has original criminal jurisdiction to try charges of common criminal offenses against the President of the Republic, the Vice-President, members of the National Congress, the Tribunal's own Ministers, and the Procurator-General of the Republic.

39 Keith S. Rosenn, Judicial Review in Brazil: Developments under the 1988 Constitution, 7 Sw. J.L. \& Trade Am. 291, 293 (2000). 
by direct action in Brazil's highest court, the Supreme Federal Tribunal (STF), or, in certain cases, before the state supreme courts (Tribunals of Justice). In short, the Brazilian system can be seen as a broad and complex scheme of judicial review, one might even say a relatively complicated one.

In terms of membership, the Court has 11 Justices, who are addressed in Portuguese as Ministro, chosen from citizens between the ages of 35 and 65, with extensive legal knowledge and being of good character. The Justices are nominated by the President with the Senate's approval. They are tenured with mandatory retirement at the age of 75, which is a general rule for all the judges in Brazil. Justices can be impeached by the Senate, in accordance with art. 52, ss. II, of the 1988 Constitution.

Every two years, members of the Supreme Court elect by secret ballot from within their membership a Chief Justice (who is called the President of the Court)..$^{40}$ A Vice- President is also elected. Re-election for a consecutive term is not allowed. The President of the Supreme Court is the third in the line of succession in the event of the incapacity of the President and Vice-President, or a vacancy in their respective offices. The President of the court is also the President of the National Council of Justice (Conselho Nacional de Justiça-CNJ) ${ }^{41}$ which is in charge of controlling the administrative and financial functioning of the judiciary and the performance of judicial duties nationwide.

The caseload of the Federal Supreme Court is extremely heavy. According to the CNJ's Supremo em Ação 2018 Report, between 2009 and 2016 there were 723,579 cases before the Court. ${ }^{42}$ In December 2016, 57,437 were still undecided, but in that same year, the Court handed down 117,426 rulings. ${ }^{43}$

\section{THE PROJECT}

Judicial institutions which provide legal mechanisms for conflict resolution play an important role in maintaining the social order of complex societies. Weaknesses in performance of their duties can contribute to conflict developing into outright violence that will be beyond the management of law and the courts. This circumstance alone indicates the need for investigations into the decision-making processes of the judiciary and the impact that these may have on maintaining the effectiveness of the rule of law.

40 Even though all the Justices as eligible for the presidency of the court, traditionally the Justices always select as president the most senior member of the court that has not yet served as President. And the Vice-Minister is generally the minister who will be elected president in the succeeding term. It is also expected that the ministers who are to be elected never cast their votes for themselves. They would choose the most senior member of the court - the "Decano" (the dean justice) or some other elder esteemed minister that the one to be elected wishes to honor. Even though the system was designed to rotate, due to the force of tradition the choices for presidency are quite predictable and usually people create expectations when certain Justices arrive into presidency. The current members of the Supreme Court are described on the official website of the court. http://www.stf.jus.br/portal/ministro/ministro.asp.

41 The duties of the CNJ are prescribed in art. 103-B, para. 4 of the 1988 Constitution.

42 https://www.cnj.jus.br/wp-content/uploads/2017/06/fd55c3e8cece47d 9945bf147a7a6e985.pdf.

43 Id. 
The object of our academic investigation has always been based on an attempt to understand what the elements that form judicial decisions are and how they are articulated, especially when dealing with constitutional themes. In other words, we work from a political concept of constitutional jurisdiction, which is conceived as the field of disputes concerning the legitimating force of institutions and citizenship rights. This has presented us with the problem of understanding what the role of the Brazilian Federal Supreme Court as custodian of the Constitution might be and the discourses that their decision-making construct. That is, we aim to explain the decisionional grammar ${ }^{44}$ of the Supreme Court as we have been doing in previous work. ${ }^{45}$ From these studies, we have found that Brazilian legal culture reflects legal inequalities ${ }^{46}$ and that there is an absence of consensus-building logic in the Justices' opinions, which contributes to continuing institutional instability and legal insecurity. We have found that the Supreme Court frequently lacks a strong level of rational consistency in the construction of those decisions that could be considered as guiding precedents for the lower courts, controlling the outcomes of new cases.

Rational consistency is taken here to be the discursive weight of the arguments produced by the Court which prevail because their rationale is convincing and persuasive and able to establish precedents to be followed by lower courts and citizens. The strength of the Court relies upon the quality of its rationales and not on the sole fact that the Court and its Justices have the power to decide. A strong level of rationality here implies that the opinions of the Justices have legitimacy because of the quality of their reasoning as opposed to relying on appeals to respect (as arguments of veneration) or the ipse dixit of self-authority. The reasoning of the Court should not rest mainly on the force of the appeal to authority (argumentum $a b$ auctoritate) but rather on the coherence, evidence, objectiveness and persuasive force of the arguments it advances. The more the Court relies on arguments of its own authority the less it can focus on the specific merits of the case in hand and in this sense a low level of rational consistency contributes to promoting a culture of arbitrary interpretations of the law. This translates into an extreme level of opacity for judicial decisions in Brazil which can lead to a low degree of adherence to

44 As we have stated before, the proposal for a grammar of judicial decisions presupposes the recognition of the discursive dimension of judicial decisions that has its own semantics of language, materialized in the speeches of the actors / interpreters of the law. And we are calling the grammar of judicial decisions the structures and rules used by the judges in their decision-making speech, constituting what Discourse Analysis calls discursive formation. Grammar is the set of individual rules used for a particular use of a language, here specifically, for the use of the judges' decision language. It is the system that organizes thinking and imposes recurrent mental structures when speaking, so that the speeches make sense to those socialized in this same sense system. Fernanda Duarte \& Rafael Mario Iorio Filho, A Gramática das Decisões Judiciais: Entre a Igualdade e a Desigualdade Jurídica, ANAIS da Associação Brasileira de Ciência Política (2010).

45 Fernanda Duarte \& Rafael Mario Iorio Filho, Supremo Tribunal Federal e Sociedade Brasileira: Legitimando a DesigualdadeJjurídica ou a Diferença?, ANAIS da $25^{\text {a }}$ Reunião da Associação Brasileira de Antropologia (2005).

46 See Roberto Kant de Lima, Polícia, Justiça e Sociedade no Brasil 13 RevisTa DE Sociologia e política 23 (1999); Roberto Kant de Lima, Direitos Civis e Direitos Humanos: Uma Tradição Judiciária Pré-republicana. 18 São Paulo PersPec. 49 (2004); Rafael Mario Iorio \& Fernanda Duarte, A Impossibilidade da Igualdade Jurídica no Brasil, 14 JuRIS PoIEsIs 47 (2011). 
norms since the meaning of the law that can be grasped through judicial decision is unclear, thereby weakening the state's promise of the rule of law. ${ }^{47}$

Through the methodology of semiolinguistic analysis of political discourse, using Patrick Charaudeau's semiolinguistic theory as a methodological guide, this article now considers the discursive procedures and categories articulated by the Justices of the Brazilian Supreme Federal Court. ${ }^{48}$ Although Charaudeau studied the relations between the persuasive force of words and their uses in the political arena, we have expanded his framework to investigate the construction of the legitimacy of legal discourse by reference to the contextual meaning of language used by the judges. So, our interest rests on the social aspects of communication and the ways judges use language to come to a decision and communicate it.

Amongst the different possibilities that discourse analysis (DA) methods offer, Charaudeau's semiolinguistic discourse analysis can help identify and clarify a grammar of judicial decisions. It enables us to understand how legal discourse is constructed, what the intentions of its enunciator are and what the organizing structures might be. This enables us to glimpse the intentions in the discourses, through what is said and unsaid, the "relations between text and context" ${ }^{49}$ and in the legal field, how these discourses are always organized by the three meaningforming places - doctrine, rhetoric and culture - with their elements of justification or legitimation..$^{50}$ Each corresponds respectively to a particular language exchange challenge: firstly, a place of elaboration of thought systems, beyond it, a place whose meaning is related to the act of communication itself, and finally, a place where commentary is produced. ${ }^{51}$ It should also be emphasized that the research that led to this article is still ongoing and, therefore, we elaborate an argument that presents our provisional reflections and hypotheses about the subject so that accordingly our results are preliminary.

\section{DATA FINDINGS}

One of the various academic challenges we face when dealing with judicial decisions is how to define a relevant corpus for analysis that is significant enough to answer the research question, supporting valid conclusions and at the same time

47 These promises can be identified in Guillermo O'Donnell's work: "the legal system is supposed to texture, stabilize, and order manifold social relations, the rule of law" [... "establishes networks of responsibility and accountability that entail that all agents, private and public, including the highest placed officials of the regime, are subject to appropriate, legally established controls of the lawfulness of their acts". Guillermo O'Donnell, Polyarchies and the (Un)Rule of Law in Latin America 23, paper presented at the Meeting of the Latin American Studies Association, Chicago, September 1998. http://lasa.international.pitt.edu/LASA98/O\%27Donnell.pdf (last visited Mar. 21, 2020).

48 See Patrick Charaudeau, Discurso Politico (2006) and Patrick Charaudeau \& Dominique Maingueneau, Dicionário de Análise do Discurso (2004).

49 Charaudeau \& Maingueneau, supra note 44, at 44.

50 See Rafael Mario Iorio Filho \& Fernanda Duarte, A Lógica do Contraditório: Ainda somos medievais (2010) https://www.academia.edu/14300522/A_lógica_do_ contraditório_ainda_somos_medievais (last visited Mar. 25, 2020).

51 Charaudeaü(2006) supra note 49. 
feasible to be handled considering constraints of time, resources and personnel that often stress research initiatives. ${ }^{52}$ From our experience, this challenge can be broken down into a two-step process. First, we have to determine where to look for the decisions, counting on a database that is reliable and easily accessible. Second, we have to deal with the selection itself, defining and refining the corpus that will be subjected to the DA.

\section{A. Building up the Corpus: Defining the Sources for Consultation \& SELECTING THE DECISIONS}

In Brazil, all judicial decisions are published in daily official reports called Diário Oficial ${ }^{53}$ which is broadly similar to the U.S. Federal Register, ${ }^{54}$ but not confined to federal government communications. Federal legislative acts, as well as judicial decisions (including courts of all tiers), are communicated to the public through these reports. At the federal level, this reporter is called Diário Oficial da União D.O.U ${ }^{55}$ and from December 1, 2017, the Brazilian News Agency has announced that only the electronic version will be available. ${ }^{56}$ This is the official source to consult if one wants to search all the cases that have been decided by the federal judiciary, and specially the Supreme Court, making this a hugely time consuming enterprise; the database was not designed for scientific purposes, but was planned as a tool for giving the parties, the lawyers and the general public acknowledgment of the decisions themselves as a requirement of fair judicial proceedings.

So other reliable sources needed to be found. In this sense, in common with many other researchers in Brazil, we have resorted to the Supreme Court's official website where the cases and their decisions are available for public consultation, amongst other historical and institutional information. ${ }^{57}$

The STF website offers a good range of searching possibilities with different entries, such as the parties' names; the register number of the case; the type of proceedings; the Justices' decisions; thematic topics; the legal provisions; etc. Amongst the possibilities we have opted to use a combination of the keywords and entries.

For the entry 'Jurisprudência' (which might roughly be translated into English as caselaw: http://portal.stf.jus.br/jurisprudencia/), we have used the keywords liberdade e religião/liberdade religiosa (freedom and religion/religious freedom).

For the entry ' $a$ Constituição e o STF' ${ }^{58}$ we have used the constitutional provision: CF art. 5, VI. We have checked our results three times in order to avoid missing cases.

52 For challenges faced in defining the corpus for analysis, see Patrick Charaudeau, Dizeme qual é teu corpus, eu te direi qual é a tua problemática. 10 Revista Diadorim (Dec. 2011). http://www.patrick-charaudeau.com/Dize-me-qual-e-teu-corpus-eu-te.html (last visited Mar. 25, 2020).

53 Also, each state member of the Brazilian Federation publishes its own Diário Oficial.

54 https://www.federalregister.gov/.

55 To check the D.O.U. website, see http://www.in.gov.br/servicos/diario-oficial-da-uniao.

$56 \mathrm{http}: / /$ agenciabrasil.ebc.com.br/geral/noticia/2017-10/edicao-impressa-do-diariooficial-deixa-de-circular-partir-de-dezembro.

57 http://www.stf.jus.br/portal/.

58 The Constitution and the STF: http://www.stf.jus.br/portal/constituicao/(last visited last visited Ap. 09, 2020). 
The general data results revealed a total of 49 cases $(25+16+8)$ as shown in the following chart.

\begin{tabular}{|c|c|c|c|}
\hline Entry & $\begin{array}{l}\text { Keyword }{ }^{1} \text { Liberdade } \\
\text { e religião }\end{array}$ & $\begin{array}{c}\text { Keyword }^{2} \\
\text { Liberdade religiosa }\end{array}$ & $\begin{array}{l}\text { Keyword }^{3} \\
C F \text { art. } 5, V I\end{array}$ \\
\hline $\begin{array}{c}\text { pesquisa de jurisprudência } \\
\text { http://portal.stf.jus.br/jurisprudencia/ }\end{array}$ & 25 & 16 & - \\
\hline $\begin{array}{c}\text { a Constituição e o STF } \\
\text { http://www.stf.jus.br/portal/constituicao/ } \\
\text { artigoBd.asp\#visualizar }\end{array}$ & - & - & 8 \\
\hline
\end{tabular}

In order to refine the cases, we have excluded those that we have found to be irrelevant bearing in mind our timeframe and our objective. We have excluded cases that were decided before 1988, those that were thematically irrelevant and those which have appeared more than once. So, eventually 38 exclusions were made and our final number of cases was 11: ADI 5.257, ADI 2.566, ADI 4.439, ADPF 54, RE 494.601, RHC 146.303, RHC 134.682, RE 859376 (tema 953), RE 979742 (Tema 952), ARE 790813 (tema 716), and STA $389^{59}$.

\section{B. THE SEMANTIC FIELD}

The idea of semantic field is related to the set of different meanings that a word (or a group of words) presents through the contexts in which it is used, revealing that words can refer to different realities within the same concept. ${ }^{60}$ Considering that the same term has or can have several different meanings in the same text, depending on how it is used and which other words accompany it, the semantic field is formed by a group of words and their associated meanings. This is linked to the concept of polysemy. The semantic fields are often related to cultural attitudes about the objects that field describes.

In our research, considering the 11 cases we have studied, we identify the following terms that integrate the semantic field which informs the concept of freedom of religion in the Brazilian Supreme Court: ${ }^{61}$

the Bible - paramount book - religious behavior - secularism - freedom of religious belief - proselytism - freedom of religious expression -

59 Unlike the United States where the names of the parties as plaintiff v. defendant are used to designate a case, in Brazil, judicial cases are cited as the type of the proceedings (e.g. $R E$ which stands for recurso extraordinário, extraordinary appeal in English) plus the docket number of the lawsuit, which is a combination of numbers given by the court when the suit is filed, for instance: ADI 5.257.

60 A semantic field does not just reflect the ideas, values and perspectives of contemporary society; it crystallizes and perpetuates them too, socializing to future generations an already elaborated analysis of the experience through which the world will be understood. See Stephen Ullmann, Principles of Semantics (1957) and Stephen UlLmanN, SEMANTICS: AN INTRODUCTION TO THE SCIENCE OF MEANING (1962).

61 As possible development of this research, for instance, would be to focus on discussion of the meaning of these words in context, revealing the values, perspectives and representations adopted by the Supreme Court that could disclose the court's attitude towards religion and the law. 
religious tolerance - confessional religious education - religious prejudice (discrimination/ "religious racism") - the Sabbath - religious ornaments - constitutional value balance - religious sentiment - boundaries for religious rights

\section{Preliminary Results}

As we have mentioned earlier this project is a work-in-progress so the set of three conclusions we are proposing as a closing for this paper should be taken as preliminary results signaling the need for further investigation to confirm these early impressions.

1. Even though the purpose of the project is to understand how the opinions of Federal Supreme Court Justices are constructed when deciding the cases concerning freedom of religion (as written in art.5, VI of the 1988 Brazilian Constitution), the first aspect that immediately calls attention is the fact that the number of cases is very small, almost "invisible" if compared to the overall docket of the Court. And even though the Constitution is almost 31 years old, all the cases have been discussed in the last decade. In a certain way, the fact that most Brazilians associate themselves with Roman Catholicism might confirm this low level of judicial litigation. Even though the data finding confirms, from the litigation perspective, that religious "conflicts are rare in Brazil" as some affirm, ${ }^{62}$ this should not be considered to demonstrate a total absence of social conflicts, as the reports previously mentioned show. ${ }^{63}$ Further investigation could adopt a qualitative/quantitative approach, trying to understand the reasons why so few cases reach the Supreme Court and showcasing the social conflict embedded in the cases.

2. Regarding the dimension of ideas and attitudes, freedom of religion is associated with beliefs, behavior and sentiment. Tolerance and prejudice are also concepts that can be found in the decisions as opposites, reflecting the common sense meaning. But secularism and proselytism are polysemic concepts for the Supreme Court which has shown difficulties in establishing semantic consensus. The lack of a clear definition of these categories impacts on the capacity of the Court to establish boundaries for acts which would be protected as the regular exercise of the religious freedom, setting them apart from those that could be considered abusive. There is a certain tendency towards the rationale of balancing values when the Court faces conflicts between freedom of religion and other fundamental rights. In this sense, we can see that the Court is aware of the legal debate, but there is no clear acknowledgment of the social (religious) conflicts which are reduced to a mere legal dispute to be solved by reference to the Justices personal view on the issue.

3. Last but not least, we could identify one category of the Brazilian decisionmaking grammar which reinforces our previous works on the subject, already referred throughout the text: the lack of consensus which produces what we call the disputatio mindset. ${ }^{64}$ The concept of disputatio mindset is a theoretical category

See e.g. Moscogliato, supra note 29.

DOS SANTOS ET AL, supra note 34, and MirAnda ET AL., id.

64 The disputatio mindset is category inspired by medieval exercises that were used by the scholastic method in western European Law schools in the $12^{\text {th }}$ and $13^{\text {th }}$ centuries. According to Berman "In addition to the readings of the texts and the glosses, and the 
which structures the Brazilian legal habitus or mind set and thereby models the reasoning and practices of the legal culture in Brazil. The ability to master and articulate its language is what permits one to navigate and function in the legal universe. However, it is a form of reasoning characterized by an open structure that inhibits the ability of participants to reach agreements, as an oppositional dynamics, whether they are parties to the conflict, legal practitioners or legal scholars. Attempts to engage with the reasoning of Brazilian judges suggest the absence of internal consensus about the knowledge produced by the Court, as one cannot point to the Court's view on the subject in question. On the contrary, what is to be found is the individual opinions of the judges which are aggregated to achieve the Court's position. The agreement here is on the outcome, but not on the reasons/ argumentation that led to it.

In this way all the opinions of the judges can be considered to be "dissenting" votes, even when together they represent the majority of the Court because the disputatio mindset does not produce the consensuses or consensual truths which could assist the Court to manage the conflicts brought before it. If the process of legal argumentation does not give clear and meaningful content to the law, it contributes little to the objective regulation of social behavior that the rule of law requires. Instead it fosters more conflicts and divergences, as it allows for the closure of the proceedings, with the choice of one of the possible interpretations of the law, and produces no clear guidelines concerning the way the conflict should be managed, treated or mediated. From this perspective the operation of the disputatio mindset will encourage more conflicts, because these are returned to society without appropriate resolution.

If socialization is a process of adaptation of the individual in society, to be achieved by the internalization of social norms (including legal ones), the absence of shared meanings leaves members of society with no direction or clear instructions. Thus, the predictability of the legal consequences of human expectations and conducts is reduced and the prospects for reducing disputes and/or conflicts before they arise are diminished. The consequence for judges lower down in the hierarchy is that once they find no safe grounds to follow the precedents set by the Supreme Court, in the absence of clear hermeneutic constraints the effect of the disputatio mindset will work to mask the prevalence of their own personal opinions

Finally, the lack of consensus concerning legal meaning has the potential to manifest itself in the unequal distribution of justice among those who are constitutionally entitled to be subjected to the "equal protection under the law" clause in Brazil. When a constitutional guarantee becomes empty rhetoric in practice, the legitimacy of the rule of law as understood by western modern societies is seriously compromised.

analysis of them though distinctions and questions, the curriculum at Bologna and other medieval law schools included the disputatio, which was a discussion of a question of law in the form of a dispute between two students under the guidance of a professor or else a dispute between professors and students. ....] but the questions were always questions of law, not actual or hypothetical situations of fact". (BERMAN, Harold. Law and revolution. The formation of the Western legal tradition. Cambridge, Massachusetts: 1983. Page 130) A more detailed explanation can be found in Iorio Filho \& Duarte, supra note 46. 